\title{
THE IMPACT OF ONLINE MARKETING IN THE PROMOTION OF UNIVERSITIES IN THE CONTEXT OF THE COVID-19 HEALTH CRISIS
}

\author{
Ruxandra-Irina POPESCU \\ Bucharest University of Economic Studies, Romania \\ irina.popescu@man.ase.ro \\ Ovidiu-Iulian BUNEA \\ Bucharest University of Economic Studies, Romania \\ ovidiu.bunea@man.ase.ro \\ Georgiana-Alexandra MEDINȚU \\ Bucharest University of Economic Studies, Romania \\ medintugeorgiana18@stud.ase.ro \\ Elena-Cătălina MAZILU \\ Bucharest University of Economic Studies, Romania \\ maziluelena17@stud.ase.ro
}

\begin{abstract}
Nowadays, social networks have become a habit for most people, the latter allocating time to check the received messages, view the published pictures and descriptions, but also the videos. Marketing has also taken this phenomenon into account. This research paper was conducted in order to identify the impact that online marketing has had on the promotion of three prestigious universities in Bucharest (Bucharest University of Economic Studies, National University of Political and Administrative Studies and the University of Bucharest) in the context of the COVID-19 pandemic. The main results highlighted the fact that during COVID-19 pandemic students use social networks frequently to find out information about the educational offers provided by universities, but also to be able to be permanently connected to the activities carried out within them.
\end{abstract}

Keywords: university, higher education, online marketing, social networks, COVID-19.

DOI: https://doi.org/10.24818/beman/2021.S.I.2-07

\section{INTRODUCTION}

"Marketing is the management process that discovers, anticipates and meets in an efficient and profitable way the needs of customers" (Institute of Marketing in Great Britain quoted by Grigorut et al., 2011). Based on this statement, we aim to identify the impact that online advertising (through social networks) has on the 
promotion of universities, as the latter are important providers of educational services. The higher education institution must formulate appropriate marketing policies to ensure the correspondence between educational and social services and the needs of consumers. Thus, creating the most suitable admission offers for candidates is not enough to carry out successful activities. Universities need to pay attention to what kind of "products" they offer, under what environmental conditions to ensure that they adequately meet the requirements of the labor market. To increase the efficiency of higher education marketing, it is necessary to determine the factors that have an impact on the choice of a university and an academic program for students.

Considering the COVID-19 health crisis, the universities had a real challenge, that of "moving" all teaching activities in the online environment, to maintain permanent contact with the public, but also to maintain their reputation to remain in the top of the best universities. Educational institutions have unconditionally used online marketing, presenting consumers with products and services that they can provide in other ways than traditional ones.

This paper aims to demonstrate the utility of online marketing as a solution to improve the promotion of important universities in Bucharest. Thus, the Bucharest University of Economic Studies which is for the third year in a row on the first place in the top economic universities in Romania and is the only university in Romania that managed to enter the top 600 universities in the world (5th place), according to the ranking of Times Higher Education World University Rankings (Bucharest University of Economic Studies, 2021a). The University of Bucharest is ranked 1,267 globally out of the 1,662 universities analyzed, while the National University of Political and Administrative Sciences is not present in this ranking which measures 13 performance indicators grouped in four areas: research activity, teaching activity, knowledge transfer to the socio-economic environment and the international perspective (Times Higher Education, 2021).

\section{LITERATURE REVIEW}

As a result of globalization and opportunities in academia, higher education institutions have begun to use educational marketing more and more to promote their offerings and attract students interested in the products and services they provide. Thus, with the help of specific marketing techniques, universities can create the most appropriate offers to satisfy the market by using the communication process, placement and pricing policies in the most efficient way (Kotler \& Fox, 1995).

The academic vision reflects two aspects of marketing. Firstly, "it represents a management philosophy that guides all the efforts of the general activities of an organization", and secondly, marketing simply 
consists of carrying out commercial activities that direct a certain flow of products and services from producer to buyer " (Dibb \& Simkin, 1997).

Filip (2012) is of the opinion that the marketing vision in the field of educational services can be defined through three approaches:

- External marketing: represents the situation in which students request information and express their desire to apply and be admitted to a certain university;

- Interactive marketing: is based on the results of all the processes created and provided by universities, such as: courses, exams, projects, applications, simulations, etc.;

- Internal marketing: refers to the processes and relationships that have in mind the exchange of information between people (transmitters, as teachers and receivers, as students) through specific means of communication (direct or intermediate communication).

Marketing plays a key role in the sustainable development of any educational institution, so it must exist mainly in the sphere of universities. Educational marketing is a well-established way that ensures a strong link between two actors in particular: the target audience (represented by current and future students) and the university itself. Consequently, a commitment arises that the higher education institution must assume: to ensure access to information on the mission and values promoted, the educational offer, study mobility, partner institutions, internships, scholarships, accommodation facilities, etc. In this context, the use of an appropriate marketing mix is an imperative for each university. Kotler \& Armstrong (2008) argue that the elements of the marketing mix are a set of specific tools that an educational institution uses harmoniously to attract its target audience (these being consumers of educational services). To clarify this idea, the four fundamental pillars in the field of education refer to:

- Product: educational services offered (course materials, books and specialized articles, elearning platforms, information and technological resources, endowments in lecture and seminar rooms, etc.);

- Price: tuition fees set according to competitors' prices and borne by students so that the institution covers its expenses with the services it provides;

- Placement: university headquarters (lecture and seminar rooms for conducting classes in physical format and e-learning platforms for conducting classes in online format);

- Promotion: transmission of information from the university to students and interested persons through communication channels (university website, social pages).

Given the aspects mentioned above, the implementation of marketing in educational services is both a complex approach, but at the same time, it is a strong need of the contemporary era. The focus of 
Popescu, R.I., Bunea, O.I., Medințu, G.A., Mazilu, E.C.

THE IMPACT OF ONLINE MARKETING IN THE PROMOTION OF UNIVERSITIES IN THE CONTEXT OF THE COVID-

19 HEALTH CRISIS

institutions on knowing and meeting consumer needs will help them identify people interested in current services and can later create more attractive offers (Paiu \& Repida, 2014).

Universities need to provide consumers with educational services that meet expectations, which will lead to the determination of competitive advantage and market position. The way in which universities are perceived by the public represents, in fact, the identity of higher education institutions, so their own business card (State, 2016). Therefore, a positive image entails a multitude of benefits, such as: increasing the notoriety of the university and the number of students who opt for the educational offer, attracting new partner organizations for student practice, obtaining Erasmus + mobility, etc. However, there may be cases where the image associated with a university is negative or misperceived by the consumers to whom it is addressed, and this has several adverse effects, including diminishing the interest of the target audience for that educational institution, the regression in the ranking of prestigious universities, the reluctance of employers towards university graduates to enter the labor market, etc.

Currently, educational institutions are looking for solutions to combat the problems generated by various causes (economic, demographic, socio-political or technology), using appropriate marketing methods and tactics. Therefore, the emergence of the crisis generated by COVID-19 and the interruption of teaching activities on campus has led to increased visibility of higher education institutions in the online environment, and distance communication has thus become the best safe way to stay in touch with students.

As can be seen in Figure 1, the onset of the pandemic had a major impact on the urgent need for people to use the Internet, so that by 2020 almost half a billion people connected online.

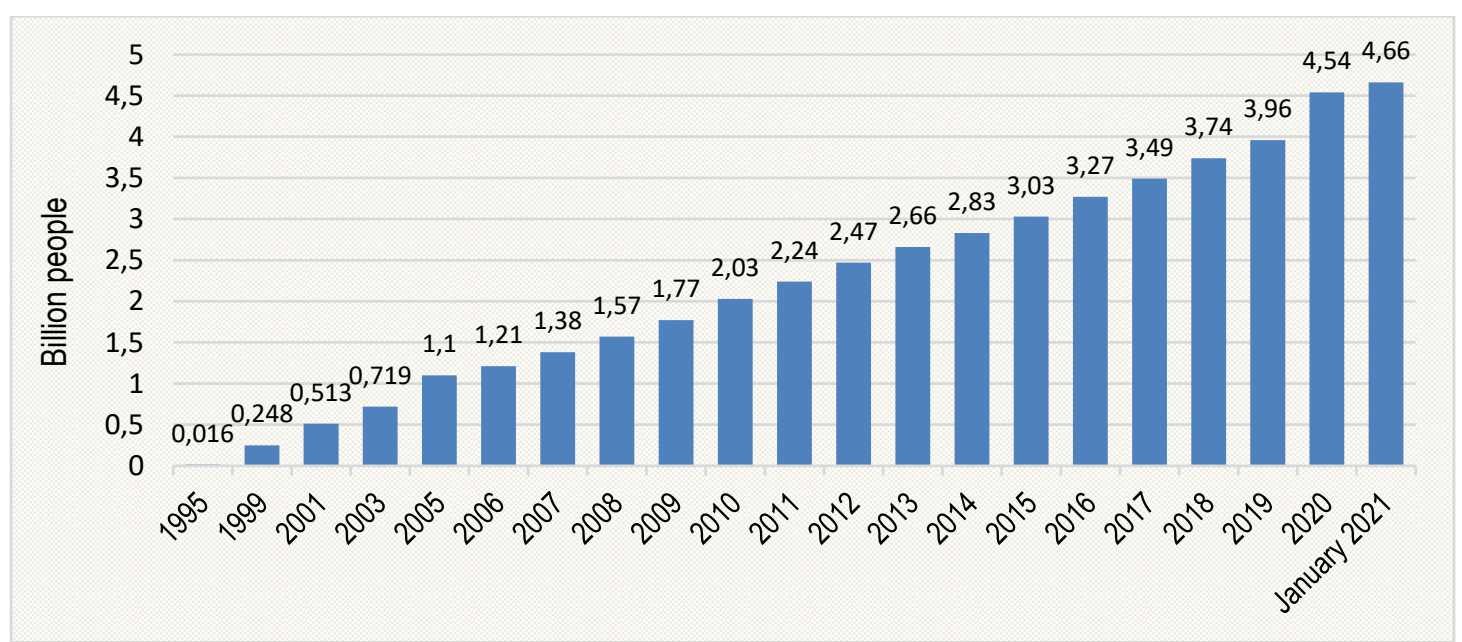

FIGURE 1. NUMBER OF INTERNET USERS WORLDWIDE FROM DECEMBER 2005 TO JANUARY 2021 Source: adapted from Choudhary (2014); Kemp (2020); Johnson (2021) 
Specialists around the world have realized the importance of online marketing and the advantages it has compared to traditional marketing, such as: it can reach customers more effectively; it is profitable; the results can be measured reliably, can be customized, etc. However, online marketing also has weaknesses, the most important being the high degree of competition (Hutapea, 2016).

Online marketing with the help of social networks is a modern and extremely popular approach among students. Social networks have completely changed the approach to marketing, allowing institutions to receive opinions, recommendations, but also comments from stakeholders, helping to improve the products and services provided. At the same time, universities manage to cover a larger area of the public through social platforms and thus create attractive offers for their clients (Constantinides, 2014).

\section{MATERIALS AND METHODOLOGY}

The aim of our study is to demonstrate the usefulness of online marketing as a solution to improve the promotion of universities in the context of the COVID-19 pandemic by: (1) identifying the main social network that students use to inform themselves; (2) establishing the degree of information of students regarding the university news published on social networks and (3) establishing the degree of influence of universities being present on social media.

One of the research tools used for this research is document analysis, through which we have analyzed various sites, reports, documents, specialized studies at national and global level, related to marketing and online marketing during time.

Another method we used is the comparison method, through which we analyzed the perceptions of respondents from three higher education institutions about the importance of online marketing in promoting universities and, with its help we were able to compare the results of their involvement in network socialization, the comparative factor being the number of followers. (Chelcea, 2001).

The questionnaire was also used, being a useful tool for data collection (Şandor, 2013). The target group was made up of first year students from the faculties with profile of "Public Administration" from the three universities: Bucharest University of Economic Studies, National University of Political and Administrative Studies, University of Bucharest, because the students went through a complex process of searching and identifying the university they will follow, while going through an online admission process, in the conditions of the COVID-19 pandemic.

The questionnaire was applied online through the platform available at http://www.isondaje.ro/ and distributed within the Facebook groups of the universities: Bucharest University of Economic Studies, National University of Political and Administrative Studies, University of Bucharest, but also within the WhatsApp groups of the first-year students, between 05.05.2021 - 31.05.2021. Thus, a number of 304 valid responses were collected. The university that had the largest contribution in data collection was the 
Popescu, R.I., Bunea, O.I., Medințu, G.A., Mazilu, E.C.

THE IMPACT OF ONLINE MARKETING IN THE PROMOTION OF UNIVERSITIES IN THE CONTEXT OF THE COVID-

19 HEALTH CRISIS

Bucharest University of Economic Studies (181 respondents), followed by the National University of Political and Administrative Studies with 69 respondents and University of Bucharest with 54 students (Figure 2).

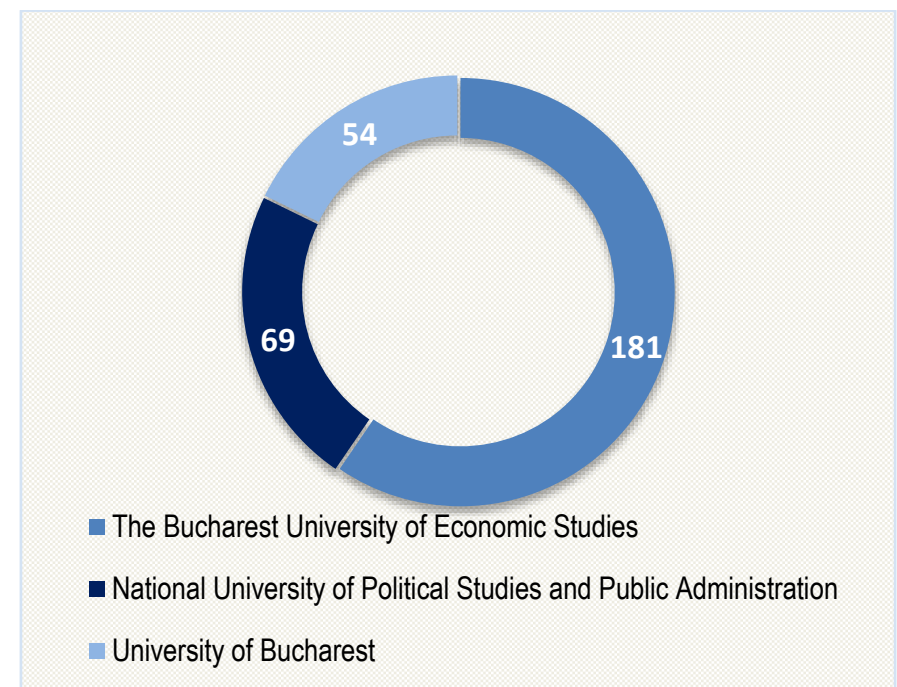

FIGURE 2. UNIVERSITIES USED FOR CONDUCTING THE COMPARATIVE ANALYSIS Source: Authors, based on results

Table 1 presents the socio-demographic data of the research sample.

TABLE 1. SOCIO-DEMOGRAPHIC DATA FOR THE RESEARCH SAMPLE

\begin{tabular}{|c|l|c|c|}
\hline \multirow{2}{*}{ CRITERION } & \multicolumn{1}{|c|}{$\begin{array}{c}\text { NUMBER OF } \\
\text { RESPONDENTS }\end{array}$} & $\begin{array}{c}\text { PERCENTAGE } \\
(\%)\end{array}$ \\
\hline \multirow{4}{*}{ Age } & $\mathbf{1 8 - 2 1}$ & 246 & 80,9 \\
\cline { 2 - 4 } & $\mathbf{2 2 - 2 5}$ & 47 & 15,5 \\
\cline { 2 - 4 } & $\mathbf{2 6 - 2 9}$ & 8 & 2,6 \\
\cline { 2 - 4 } & over 30 & 3 & 1 \\
\hline \multirow{2}{*}{ Gender } & Female & 186 & 61,2 \\
\cline { 2 - 4 } & Male & 118 & 38,8 \\
\hline \multirow{2}{*}{ Area } & Urban & 204 & 67,1 \\
\cline { 2 - 4 } & Rural & 100 & 32,9 \\
\hline
\end{tabular}

Source: Authors based on the results of the study

\section{RESULTS AND DISCUSSION}

\section{Bucharest University of Economic Studies}

The Bucharest University of Economic Studies has enjoyed an increase in the number of accesses from students, but also from teachers on the social pages of the institution and on sites that provide information of interest with the transfer of all university activities in the online format. An example in this sense is the Blended Learning platform (www.online.ase.ro) which was a very useful tool for the transmission of teaching materials by teachers, uploading homework and projects made by students, but also for 
communication between students and teachers, along with audio-video platforms such as Zoom or Google Meet. Moreover, the Bucharest University of Economic Studies has taken measures to maintain a permanent link between the human resources of the institution during the COVID-19 crisis, so that subscriptions have been purchased on the Zoom platform through which students and teachers benefit from online meetings without time limit (Bucharest University of Economic Studies, 2021b).

\section{National University of Political and Administrative Studies}

The website of the National University of Political and Administrative Studies has a professional design and contains all the necessary information for the target group: public information, admission, study programs, academic journals, projects, information about accommodation, scholarships, careers, etc. Given the pressure from universities in Bucharest, the university has increased the degree of involvement on the Instagram page, by posting constantly. The results of the analysis of the promotion strategy underline the fact that it considers trends and progresses compared to the previous year. Online marketing is essential and at the same time mandatory for universities because the latter adapt to the requirements of the current generation, which is constantly changing (NUPAS, 2021).

\section{University of Bucharest}

The University of Bucharest was in a position where it had to develop a well-developed online promotion strategy, through which potential students could receive the necessary information. Thus, to ensure transparency, the university has set up the Communication, Public Relations and Marketing Department, whose mission is to maintain the connection between the university and its public and to provide them with relevant information both online and offline (UniBuc, 2021).

Tables 2 and 3 highlight the degree of visibility of universities for future students who want to benefit from the educational services offered within the three higher education institutions. It is noteworthy that the Bucharest University of Economic Studies appeared on Instagram only at the end of January this year, but in less than 8 months the official account of the university exceeded the number of 1,000 followers, constantly posting information which targets both current students and graduates of other educational institutions seeking to continue their studies at the university.

TABLE 2. COMPARATIVE TABLE ON THE YEAR OF REGISTRATION ON SOCIAL NETWORKS

\begin{tabular}{|c|c|c|c|}
\hline \multirow{2}{*}{$\begin{array}{c}\text { SOCIAL } \\
\text { NETWORKS }\end{array}$} & YEAR OF REGISTRATION ON SOCIAL NETWORKS \\
\cline { 2 - 4 } & BUES & NUPAS & $\begin{array}{c}\text { UNIVERSITY OF } \\
\text { BUCHAREST }\end{array}$ \\
\hline Facebook & 28 July 2011 & 23 September 2012 & 14 December 2009 \\
\hline YouTube & 15 February 2011 & 15 July 2014 & 15 December 2015 \\
\hline Instagram & 25 January 2021 & 20 January 2020 & 30 May 2017 \\
\hline Twitter & February 2011 & November 2012 & January 2010 \\
\hline \multicolumn{4}{|c}{ Source: Authors }
\end{tabular}


Popescu, R.I., Bunea, O.I., Medințu, G.A., Mazilu, E.C.

THE IMPACT OF ONLINE MARKETING IN THE PROMOTION OF UNIVERSITIES IN THE CONTEXT OF THE COVID-

19 HEALTH CRISIS

TABLE 3. COMPARISON TABLE ON FOLLOWERS ON SOCIAL NETWORKS AT THE BEGINNING OF SEPTEMBER 2021

\begin{tabular}{|c|c|c|c|}
\hline \multirow{2}{*}{$\begin{array}{c}\text { SOCIAL } \\
\text { NETWORKS }\end{array}$} & BUES & NUPAS & $\begin{array}{c}\text { UNIVERSITY OF } \\
\text { BUCHAREST }\end{array}$ \\
\cline { 2 - 4 } & FOLLOWERS \\
\hline Facebook & 43.152 people & 24.753 people & 99.549 people \\
\hline YouTube & 151 subscribers & 158 subscribers & 1.460 subscribers \\
\hline Instagram & 1.065 followers & 1.831 followers & 8.207 followers \\
\hline Twitter & 385 followers & 593 followers & 1.408 followers \\
\hline Linkedln & 100.835 followers & 14.629 followers & 90.013 followers \\
\hline
\end{tabular}

Source: Authors

Figure 3 shows the social networks on which respondents are active. The most beloved and used network is Instagram, but Facebook is also very close to students' preferences. Even though it is a young platform, TikTok has conquered internet users, something that cannot be said about Twitter, which has dropped considerably in the respondents' elections.

Regarding the frequency of using social networks, according to the data collected, it turned out that 285 students, i.e., over $93 \%$ use social platforms daily, which suggests the desire to stay connected to the news generated by daily changes.

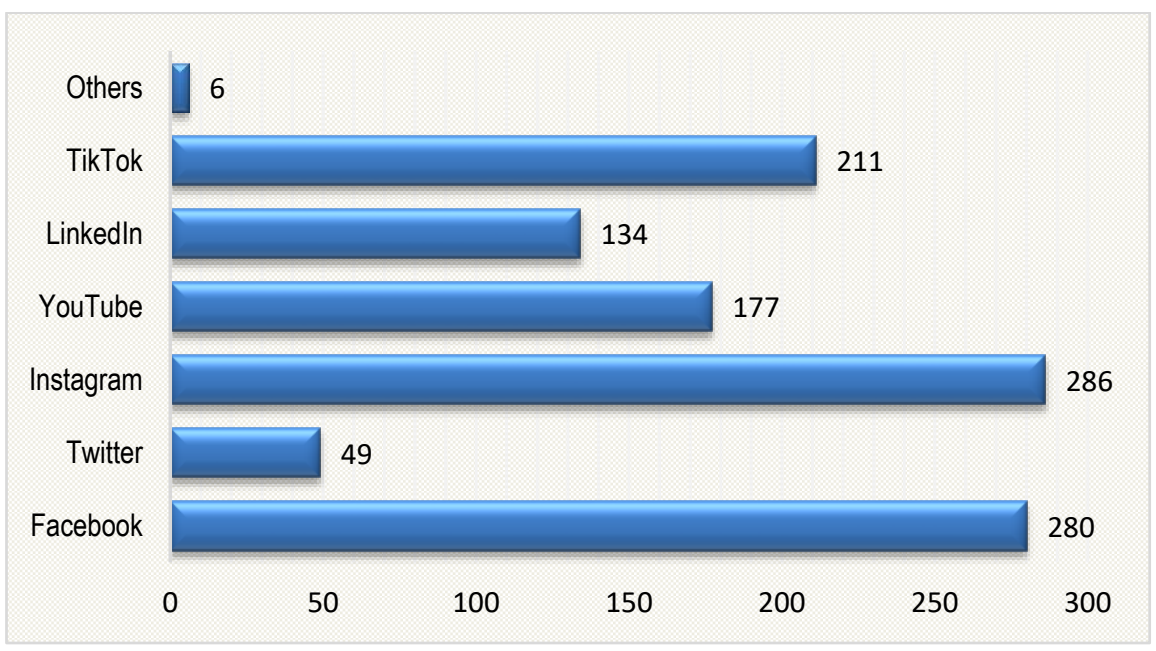

FIGURE 3. SOCIAL NETWORKS USED BY RESPONDENTS

Source: Authors based on the results of the study

After completing high school, respondents were informed about the university program that they would eventually follow in various ways, but the most successful means were the official website of the university, the official Facebook page, the official Instagram page and friends / former students, these options being chosen more than 100 times, which underlines the importance of the presence of 
universities on social platforms (Figure 4). The least used method of gathering information was the official YouTube channel.

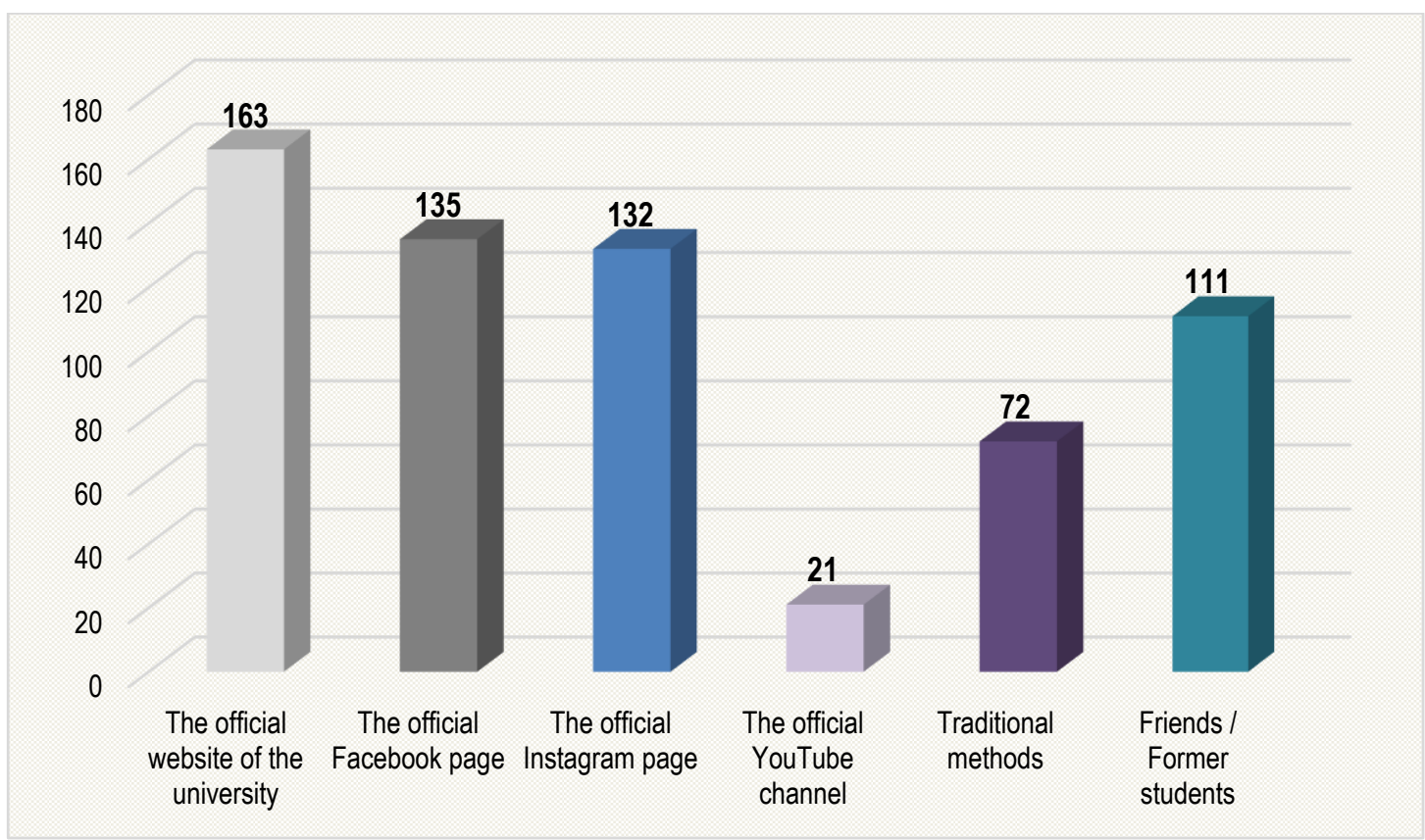

FIGURE 4. INFORMATION METHOD REGARDING THE UNIVERSITY PROGRAM

Source: Authors based on the results of the study

In Table 4 we presented the students' perceptions about the impact that social networks have on the promotion of universities.

TABLE 4. PERCEPTIONS ON SOCIAL NETWORKS

\begin{tabular}{|c|c|c|c|c|c|}
\hline & $\begin{array}{c}\text { To a very } \\
\text { large extent }\end{array}$ & $\begin{array}{c}\text { To a large } \\
\text { extent }\end{array}$ & $\begin{array}{c}\text { To some } \\
\text { extent }\end{array}$ & $\begin{array}{c}\text { To a lesser } \\
\text { extent }\end{array}$ & $\begin{array}{c}\text { To a very } \\
\text { small extent }\end{array}$ \\
\hline Facebook & $180(59,4 \%)$ & $57(18,8 \%)$ & $37(12,2 \%)$ & $13(4,3 \%)$ & $16(5,3 \%)$ \\
\hline Instagram & $187(61,7 \%)$ & $55(18,2 \%)$ & $37(12,2 \%)$ & $18(5,9 \%)$ & $6(2 \%)$ \\
\hline Linkedln & $44(14,5 \%)$ & $46(15,2 \%)$ & $114(37,6 \%)$ & $38(12,5 \%)$ & $61(20,1 \%)$ \\
\hline Twitter & $26(8,6 \%)$ & $17(5,6 \%)$ & $67(22,1 \%)$ & $32(10,6 \%)$ & $161(53,1 \%)$ \\
\hline YouTube & $75(24,8 \%)$ & $76(25,1 \%)$ & $86(28,4 \%)$ & $25(8,3 \%)$ & $41(13,5 \%)$ \\
\hline \multicolumn{7}{|c|}{ Source: Authors based on the results of the study }
\end{tabular}

As resulting from answering the question "What is your preferred method of informing about university news?" respondents prefer to keep up to date with university news through the official website, but at the same time they chose the social network, Instagram, where with the help of a photo or a video and a description you can find out interesting information in a relatively short time. 108 students admit that the news sent on the WhatsApp application by competent people are more useful. 
Popescu, R.I., Bunea, O.I., Medințu, G.A., Mazilu, E.C.

THE IMPACT OF ONLINE MARKETING IN THE PROMOTION OF UNIVERSITIES IN THE CONTEXT OF THE COVID-

19 HEALTH CRISIS

Considering the extent to which respondents use social networks for information, 100 access the news posted by the university every week, 83 access social networks whenever they need correct and concrete information, 79 daily, 38 monthly and 4 do not consider social networks relevant to obtain accurate information, so they never use social platforms for this purpose.

Following the assessment of the need for the presence of universities on social networks, the average response is 4.59 (on a scale from 1 to 5). 217 respondents believe that the presence of universities on social platforms is very useful, being the method through which many high school graduates can be reached.

The answers to the question regarding the perception of the respondents in terms of the quality and quantity of the information published on the site or on social platforms are mostly positive, 233 stating that they are very satisfied, respectively satisfied with clarity / coherence. 8 students are dissatisfied, 4 are very dissatisfied and admit that there are still things to improve. The average of the answers after evaluating all 304 respondents is 4.37 (on a scale of 1 to 5 ).

The recommendations of the target group for improving the presence of universities on social networks (Figure 5) are structured as follows: 74 of them advise institutions to use paid promotion, 62 to outsource platform and site maintenance, 53 to improve the BUES official website, 48 suggested creating a TikTok account, 36 expressed a desire for higher quality posts and 31 want online tours inside the buildings.

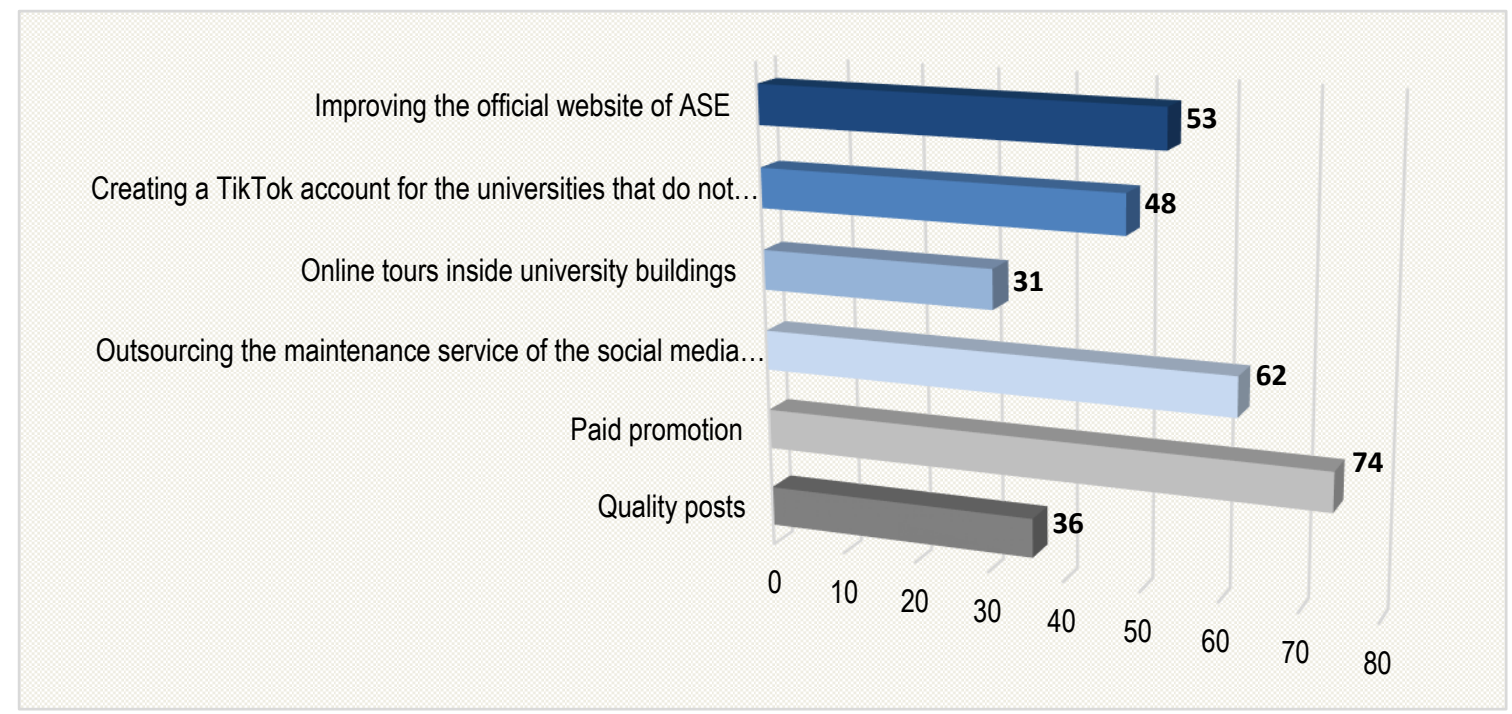

\section{FIGURE 5. TARGET GROUP RECOMMENDATIONS FOR IMPROVING THE PRESENCE OF UNIVERSITIES ON SOCIAL NETWORKS}

Source: Authors based on the results of the study 


\section{CONCLUSION}

In conclusion, the aim of the study was achieved as we identified during pandemic times that (1) the main social network that students use for gathering information about university activity, is Instagram, closely followed by Facebook; (2) students are using social networks for keeping up to date with university activities in a very high degree and (3) students have the perception that universities being present on social networks can have a very high degree of influence on actual and potential students.

During COVID-19 pandemic changes in universities have stimulated competition, so institutions have adapted and worked to improve their curricula, although this has not significantly contributed to building a favorable reputation among stakeholders.

Students are the business card of universities; they have an essential role in improving the image of such institutions. Closely connected with people are social networks, which have become a vital need today, facilitating the access of new generations to various information, which they can access from their own comfort.

One of the limitations faced by this research was shown when we had to apply the questionnaire, because it was quite difficult to communicate with first-year students enrolled at the National University of Political and Administrative Studies and the University of Bucharest. The small number of respondents outlined another limit that was generated by both communication difficulties and the reluctance of students in answering the questions.

\section{REFERENCES}

Bucharest University of Economic Studies (2021a). Comunicat de presă din 2 septembrie 2021.

Retrieved September 5, 2021, from:

https://www.ase.ro/ase_responsive/Stiri_evenimente/septembrie2021/Comunicat_de_presa_ASE_I

N_CLASAMENTUL_TIMES_HIGHER_EDUCATION_2022.pdf.

Bucharest University of Economic Studies (2021b). Marketing și comunicare. Retrieved August 4, 2021, from: https://comunicare.ase.ro/.

Chelcea, S. (2001). Metodologia cercetării sociologice. Metode cantitative şi calitative. București: Economic Publishing House.

Choudhary, A. (2014). The Growth in Internet and Telecom Users in India During Q2 2014 Disappoints. Retrieved July 21, 2021, from: https://dazeinfo.com/2014/11/19/growth-internet-telecom-users-indiaq2-2014-disappoints/

Constantinides, E. (2014). Foundations of Social Media Marketing. Procedia - Social and Behavioral Sciences. 148: 40-57.

Dibb, S., \& Simkin, L. (1997). A program for implementing market segmentation. Journal of Business \& Industrial Marketing.

Filip, A. (2012). Marketing theory applicability in higher education. Procedia-social and behavioral sciences. 46: 912-916. 
Popescu, R.I., Bunea, O.I., Medințu, G.A., Mazilu, E.C.

THE IMPACT OF ONLINE MARKETING IN THE PROMOTION OF UNIVERSITIES IN THE CONTEXT OF THE COVID-

19 HEALTH CRISIS

Grigoruț, C., Ploae, V., Zăgan, R., Micu, A. \& Zaharia, R. (2011). Marketing universitar. București: Ediție online, UEFISCDI.

Hutapea, J. Y. (2016). The Evolution on Marketing Concept: Analysis on the Perspective Changes in Marketing Concept. Journal of International Scholars Conference, 1(3): 66-76.

Johnson, J. (2021). Global number of internet users 2005-2019. Retrieved July 21, 2021, from: https://www.statista.com/statistics/273018/number-of-internet-users-worldwide/

Kemp, S. (2020). Digital 2020 reports. Retrieved July 21, 2021, from: https://wearesocial.com/blog/2020/01/digital-2020-3-8-billion-people-use-social-media

Kotler, P. \& Fox, K. (1995). Strategic Marketing for Educational Institutions (ed. 2). Englewood Cliffs, N.J: Prentice Hall.

Kotler , P., \& Armstrong, G. (2008). Principiile marketingului (ed. a IV-a). București: Teora.

Paiu, M., \& Repida, T. (2014). Marketingul educational-componentă indispensabilă a managementului strategic universitar în condiţile noilor provocări. Studia Universitatis Moldaviae (Seria Ştiinţe ale Educaţiei), 79(9), 43-47.

NUPAS (2021). Despre noi. Retrieved August 7, 2021, from: http://snspa.ro/snspa/despre-noi/

Şandor, S. D. (2013). Metode şi tehnici de cercetare în ştiinţele sociale. Cluj: Tritonic.

State, A. M. (2016). Comunicare narativă şi identitatea branding-ului universitar. Revista română de sociologie, serie nouă, anul XXVII, nr. 3-4, 317-328.

UniBuc (2021). UB Astăzi. Retrieved August 10, 2021, from: https://unibuc.ro/despre-ub/ub-astazi/scurtaprezentare

Times Higher Education (2021). World University Rankings, 2021. Retrieved August 16, 2021, from: https://www.timeshighereducation.com/world-university-rankings/2022/world-

ranking\#!/page/0/length/-1/sort_by/rank/sort_order/desc/cols/stats 